\title{
Biology and parasites of Pteronotus gymnonotus from the Caatinga shrublands of Ceará (Brazil)
}

\author{
Shirley Seixas Pereira da Silva ${ }^{1 *}$, Patricia Gonçalves Guedes'1 ${ }^{1}$ Flávia Silva Severino', and Juliana Cardoso de Almeida² \\ ${ }^{1}$ Instituto Resgatando o Verde - IRV. Rua Tirol, 536, sala 609, Freguesia, Rio de Janeiro - RJ, C.P. 22750-009, Brazil. E-mail: \\ batshirley@gmail.com (SSPDS), pgguedes@gmail.com (PGG), flasilva35@gmail.com (FSS). \\ ${ }^{2}$ Instituto Resgatando o Verde - IRV. Rua Tirol, 536, sala 609, Freguesia, Rio de Janeiro - RJ, 22750-009, Brazil. Universidade Iguaçu \\ (UNIG). Av. Abílio Augusto Távora, 2134, Nova Iguaçu - RJ, C.P. 26260-0454, Brazil. Centro Universitário Geraldo di Biase (UGB). \\ Rodovia Benjamim lelpo, km 11, Parque São José, Barra do Piraí - RJ, C.P. 27101-970, Brazil. E-mail: julianaallmeida@gmail.com. \\ *Corresponding author
}

\begin{abstract}
Mormoopid bats are distributed from southern United States of America to Brazil and comprise the genera Mormoops and Pteronotus. Although forms of Mormoops in Bahia, Brazil were described for the Quaternary, only some of the extant species of Pteronotus occur in this country, including P. gymnonotus. The species distribution ranges from southeastern México to northeastern Bolivia and central Brazil. This work presents information about food preference, reproduction, and the ectoparasitological fauna of $P$. gymnonotus in the state of Ceará. Fieldwork took place over ten consecutive days in the rain and dry seasons, in 2000, 2012, 2013, and 2019, on trails within the Serra das Almas Private Natural Heritage Reserve. A total of 14 P. gymnonotus specimens were caught in the three main phytophysiognomies present in the region. They were inspected for ecto and endoparasites, and fecal material was collected and analyzed under a light microscope. Of the total collected females, four were pregnant and one was lactating in January, during the rain season. No food residues or evidence of endoparasites were observed in the gastric content of the animals. Regarding the fecal samples, fragments of insects were found and identified as belonging to the orders Coleoptera and Lepidoptera. Seven individuals were infested with ectoparasites of the subfamily Acari and newly described associations with Diptera genera are presented. Due to the scarcity of data about these bats in the Caatinga biome, data reported here help explain the ecological interactions of P. gymnonotus in this semiarid area in Brazil.
\end{abstract}

Los murciélagos Mormopidos se distribuyen desde el sur de los Estados Unidos de América hasta Brasil y comprenden los géneros Mormoops y Pteronotus. Aunque las formas de Mormoops son conocidas para el Cuaternario de Bahía, Brasil, solamente algunas de las especies recientes de Pteronotus se encuentran en este país. La distribución de la especie comprende desde el sureste de México hasta el noroeste de Bolivia y centro de Brasil. Este estudio presenta información sobre la preferencia alimentaria, reproducción y fauna ectoparasitológica de P. gymnonotus en el Estado de Ceará. El trabajo de campo se llevó a cabo durante diez días consecutivos en las estaciones lluviosa y seca en los años 2000, 2012, 2013 y 2019 en senderos dentro de la Reserva Privada del Patrimonio Natural Serra das Almas. Se capturaron un total de 14 especímenes de $P$. gymnonotus en las tres principales fitofisionomías presentes en la región. Fueron inspeccionados en busca de ecto y endoparásitos y el material fecal se recogió y analizó con un microscopio óptico. Del total de hembras recolectadas en enero, cuatro estaban preñadas y una en lactancia, durante la época de lluvias. No se observaron residuos de alimentos ni evidencia de endoparásitos en el contenido gástrico de los animales. En cuanto a las muestras fecales, se encontraron fragmentos de insectos que se identificaron como pertenecientes a los órdenes Coleoptera y Lepidoptera. Siete individuos encontraron infestados por ectoparásitos pertenecientes a la subfamilia Acari y se presentan nuevas asociaciones con géneros del orden Diptera. Debido a la escasez de datos sobre estos murciélagos en el Bioma de Caatinga, los datos presentados aquí ayudan a comprender las interacciones ecológicas de P. gymnonotus en una zona semiárida de Brasil.

Keywords: diet; ectoparasite; geographic distribution; hemoparasite; reproduction.

(C) 2021 Asociación Mexicana de Mastozoología, www.mastozoologiamexicana.org

\section{Introduction}

Of the 1,386 species of bats in the world (Burgin et al. 2018), the greatest biodiversity occurs in Brazil where there are 182 species (Nogueira et al. 2018; Quintela et al. 2020). The Mormoopidae was recognized as a family by Smith(1972); previously it was part of the family Phyllostomidae. This group of bats occurs from southern United States of America (U.S.A.) to Brazil and comprises the genera Mormoops and Pteronotus. Although forms of Mormoops in Bahia, Brazil were described for the Quaternary (Czaplewski and Cartelle 1998), only mormoopid extant species occur in this country: Pteronotus alitonus, P. gymnonotus, P. personatus, and P. rubiginosus.

Studies by Mares et al. (1981), Willig (1983) and Willig and Mares (1989) on the chiropterofauna of the Brazilian shru- bland areas report the occurrence of $P$. davyi in the states of Ceará and Piauí. Later, Simmons (2005) and Patton and Gardner (2007) considered P. gymnonotus as a junior synonym of $P$. davyi, and thus these authors did not recognize the occurrence of this species in Brazil. The distribution of $P$. gymnonotus ranges from southeastern Mexico to northeastern Bolivia and central Brazil (Pavan and Tavares 2020). The first record of $P$. gymnonotus for the state of Ceará was published by Mares et al. (1981), who mistakenly identified specimens collected in the municipality of Crato as P. davyi (Patton and Gardner 2007). However, studies carried out in the Crato region, and the municipalities of Crateús and Aiuaba (Novaes 2012; Novaes and Laurindo 2014; Silva et al. 2015; Feijó and Rocha 2017), confirmed the occurrence of $P$. gymnonotus in this state. 
Mormopids are found up to $3,000 \mathrm{~m}$ elevation and inhabit caves, rock crevices, open areas and dry deciduous and humid forests (Herd 1983; Patton and Gardner 2007). They are classified as aerial insectivorous bats (Simmons and Conway 2001; Ladle et al. 2012) and their diet consists mainly of insects of the order Coleoptera, as well as other hexapods, such as those belonging to the orders Lepidoptera, Diptera, Orthoptera, Hymenoptera, Hemiptera and Odonata (Rolfe and Kurta 2012).

Machado-Allison (1965) highlighted the high degree of specificity between Cameronieta species (Acari) and their respective hosts and advocated for the removal of Chilonycterine bats from the family Phyllostomidae. Subsequently, Smith (1972a) showed that ectoparasites of spinturnicid mites and flies found in mormopids are different from those recorded in phyllostomid bats.

The list of ectoparasites associated with P. gymnonotus includes the mite Cameronieta sp. (Almeida et al. 2016), Dipterans Trichobius johnsonae and Nycterophilia fairchildi (Figueiredo et al. 2015; Dick et al. 2016), and the tick Ornithodoros marinkellei (Luz et al. 2016). Regarding endoparasitic fauna, there are no records of helminths infesting these bats, only the presence of protozoan hemoparasites (Lima et al. 2015). Due to the scarcity of data on ecological associations of mormoopid bats in the Caatinga biome (northeastern Brazilian shrublands), this work provides information on food preference, reproduction, and evidences of new ectoparasites in association to P. gymnonotus in the state of Ceará.

\section{Material and Methods}

Fieldwork took place over ten consecutive days in the rain and dry seasons of 2000, 2012, 2013 and 2019, on trails within the Serra das Almas Private Natural Heritage Reserve (SANR; $-5^{\circ} 5^{\prime}$ to $-5^{\circ} 15^{\prime} \mathrm{S},-40^{\circ} 50^{\prime}$ to $-41^{\circ} 00^{\prime} \mathrm{W}$ ) in the western part of Ceará State. The reserve is 5,845 ha (Figure 1) and was recognized in 2018 by the Latin American Network for the Conservation of Bats (RELCOM) as the first "Area of Importance for the Conservation of Bats" (AICOM - A-BR002) in the Caatinga biome. The climate of the region is BSh (semi-arid climate) according to the Köppen classification system (Alvares et al. 2013), with a dry summer and an average annual temperature of $26.5^{\circ} \mathrm{C}$. Rain is highly irregular, which is typical for this Brazilian semiarid zone. The average rainfall is $870 \mathrm{~mm} /$ year, the rain season occurs from January to May, and the dry season occurs from June to December (INMET 2020). Three main phytophysiognomies of Caatinga vegetation, in different successional stages, are in the reserve: dry forest, carrasco scrub, and arboreal caatinga (Associação Caatinga 2012).

Bats were captured using eight mist nets extended from 18 to $24 \mathrm{~h}$, at elevations varying from 569 to 700 masl, in the three main phytophysiognomies in the region. Fecal samples were placed in plastic microtubes, ectoparasites were removed with fine-tipped tweezers and hematological slides were made according to Baptista and Esbérard (1997) to verify the occurrence of hemoparasites. For each speci- men body measurements (total lenght, forearm, foot, ear, tibia, calcaneus and tail) were obtained using a digital caliper; weight and reproductive condition were also recorded.

Abdominal and thoracic cavities of necropsied specimens were examined to search for endoparasites. The fragments of insects found in the feces were mounted on permanent slides. Blood smears were prepared by using the "Panotic" rapid staining method $\left(\mathrm{NewProv}^{\circledR}\right)$ and observed using a Biofocus optical microscope (model Bio1600 BA-H; 100x and 400x). Dipterans were identified using a stereomicroscope (40x) and based on descriptions and keys by Wenzel et al. (1966) and Guerrero (1993; 1994; 1995). Mites were prepared using a clarification method following the Flechtmann (1990) technique, mounted on slides with a cover slip, and identified using the taxonomic key by Machado-Allison (1965). The bat specimens collected as vouchers are in the Adriano Lúcio Peracchi Collection (ALP-UFRRJ), currently housed at the Federal Rural University of Rio de Janeiro (UFRRJ / RJ), and the slides with the ectoparasites were deposited in the Acarological Collection at the Oswaldo Cruz Foundation FIOCRUZ (Rio de Janeiro - RJ). The capture and collection of specimens was authorized by the Chico Mendes Institute for the Conservation of Biodiversity (ICMBio) of the Brazilian government (authorization number 32684-1).

\section{Results}

From a sampling effort (Straube and Bianconi 2002) of $103,313 \mathrm{~m}^{2} \mathrm{~h}$, a total of 14 P. gymnonotus specimens (12 females and two males) were caught between 620 and 700 masl elevation in the three phytophysiognomies in the region (Appendix 1). Of the total collected females $(n=12)$, four were pregnant and one was lactating (producing milk in the breast) in January, during the rain season. Two males and seven females were sexually inactive and were collected in both dry and rain seasons. Biometric data from these specimens are available in Table 1.

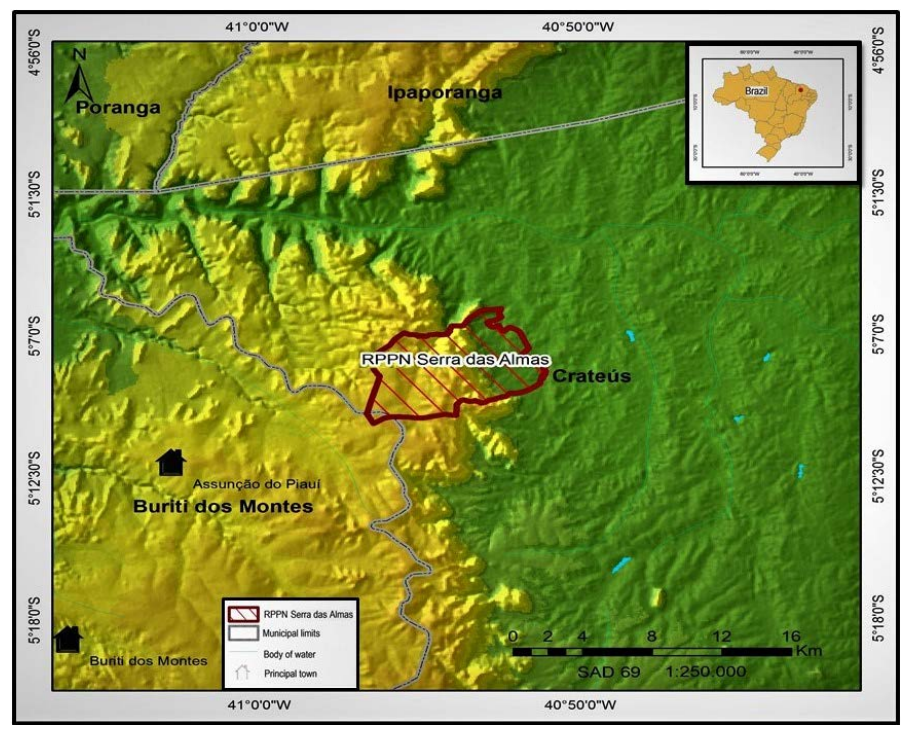

Figure 1. Location of Serra das Almas Private Natural Heritage Reserve in Crateús (Ceará, Brazil; Software ArcGis 10.1- Esri Maps; Prepared by: Sergio Carvalho Moreira, modified by Shirley Seixas Pereira da Silva). 
Table 1. Mean biometric (in $\mathrm{mm}$ ) data from P. gymnonotus specimens from Crateús (Ceará, Brazil).

\begin{tabular}{lcc}
\hline & Pteronotus gymnonotus \\
& Males $(\boldsymbol{n}=\mathbf{2})$ & Females $(\boldsymbol{n}=\mathbf{1 2})$ \\
\hline Weight $(\mathrm{g})$ & $11.0-13.0$ & $10.0-17.0$ \\
Total lenght & $46.6-54.1$ & $48.8-57.4$ \\
Forearm & $48.7-51.0$ & $48.4-51.2$ \\
Ear & $12.8-17.6$ & $11.9-18,7$ \\
Tibia & $21.0-21.6$ & $18.1-22.0$ \\
Foot & $9.5-10.7$ & $9.1-11.5$ \\
Tail & $20.6-22.7$ & $16.1-21.3$ \\
\hline
\end{tabular}

Of the $P$. gymnonotus specimens captured, it was possible to analyze the gastrointestinal content and fecal samples of three and 13 specimens, respectively. For three bats, both gastrointestinal and fecal samples were analyzed. No food residue or evidence of endoparasites was observed in the gastric content of the animals. Regarding the fecal samples, fragments of insects were found and identified as belonging to the orders Coleoptera and Lepidoptera (Figure 2). Some fragments were crushed, which made it impossible to identify them (38.2\%). The Coleoptera families consumed by bats in SANR were identified as Carabidae and Elateridae (Figure 3). Regarding the order Lepidoptera, the wing scales found were associated with the family Sphingidae (hawk moths: Figure 3).

When comparing diet between males and females of $P$. gymnonotus in our sample at SANR, both consumed Lepidoptera in dry and rain periods; only males consumed coleopterans in the rain season; the Coleoptera / Lepidoptera combination was consumed only by females in the rain season.

Seven individuals of $P$. gymnonotus were infested with ectoparasites. Specimens of the order Diptera and subfamily Acari were collected after checking the coat, patagium and uropatagium of the bats (Figure 3). Dipterans of Streblidae were identified as Nycterophilia parnelli (ALP 10194), Megistopoda aranea (ALP 10390), and Trichobius johnsonae (ALP 10386; ALP 10389; ALP 10422). Mite specimens were identified as Cameronieta sp. (Spinturnicidae).

Three bats were infested with both mites and dipterans, and one specimen had two Diptera species in its coat (Table 2). Regarding endoparasitic fauna, there were

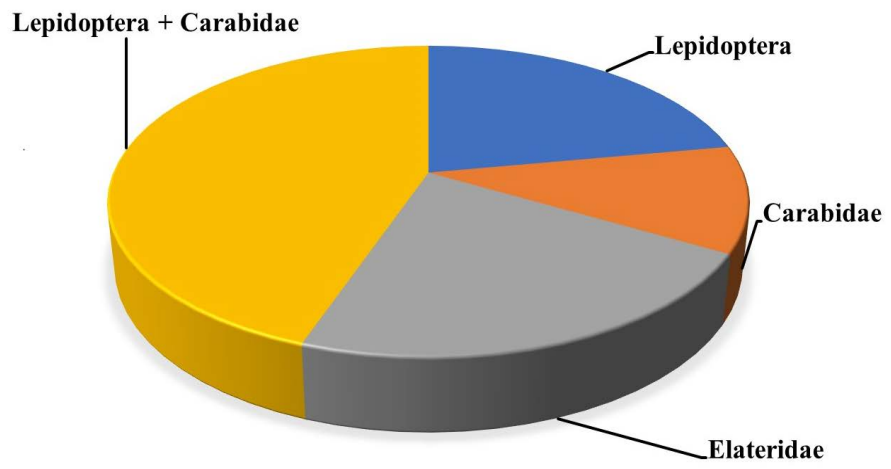

Figure 2. Food preferences of 13 P. gymnonotus specimens from Crateús (Ceará, Brazil). no records of infestation by helminths in the three bats inspected, and the analysis of the hematological slides did not show presence of hemoparasites.

Table 2. Ectoparasites found in association with P. gymnonotus from Crateús (Ceará, Brazil).

\begin{tabular}{|c|c|c|c|c|}
\hline \multirow{3}{*}{ Bats } & \multicolumn{3}{|c|}{ Ectoparasites } & \multirow[b]{3}{*}{$\begin{array}{c}\text { Megistopoda } \\
\text { aranea }\end{array}$} \\
\hline & Spinturnicidae & & Streblidae & \\
\hline & Cameronieta sp. & $\begin{array}{l}\text { Trichobius } \\
\text { johnsonae }\end{array}$ & $\begin{array}{c}\text { Nycterophilia } \\
\text { parnelli }\end{array}$ & \\
\hline ALP 10194 & & & $2 q$ & \\
\hline ALP 10386 & $1 \delta^{\lambda}$ & $1+$ & & \\
\hline ALP 10389 & & $10 / 2 q$ & & \\
\hline ALP 10390 & & & & $10 / 1 q$ \\
\hline ALP 10422 & $1 \mathrm{pn} / 3 \hat{\jmath}$ & $20 / 3 q$ & & \\
\hline REG 188 & $1 \mathrm{pn}$ & & $1 \delta^{\lambda}$ & \\
\hline REG 201 & $10^{\pi}$ & & & \\
\hline REG 314 & & 1 우 & & \\
\hline REG 362 & & $1 \delta / 19$ & 1 웅 & \\
\hline
\end{tabular}

\section{Discussion}

Pteronotus gymnonotus is an aerial insectivorous bat species that uses closed spaces as a foraging and feeding strategy, in the lower strata of the canopy and understory, and occurs in dry environments at elevations up to 1,000 masl (Norberg and Rayner 1987; Bredt et al. 1999; Denzinger and Schnitzler 2013; Novaes and Laurindo 2014; Pavan and Tavares 2020). In the Serra das Almas Private Natural Heritage Reserve, individuals were collected in the understory in all three phytophysiognomies in the area, at elevations ranging from 620 to 700 masl, confirming the pattern found for the species by previous studies.

Silva et al. (2015) publication on the biodiversity of bats in SANR included P. gymnonotus, but these authors did not record the new area of distribution of the species in Ceará State. The records of specimens near to the border of Piauí State extends its distribution to the north by $167 \mathrm{~km}$ in relation to the municipality of Aiuaba and $266 \mathrm{~km}$ in relation to the municipality of Crato, locations in Ceará where the occurrence of the species has already been registered.

Measurements taken from SANR $P$. gymnonotus specimens are in accordance with those previously published (Pavan and Tavares 2020). The reproductive pattern known for mormoopid bats is the seasonal monoestrous type, where pregnancy occurs from January to May and the offspring is born at the end of the rain season, giving birth to one young per pregnancy (Nowak 1994; Reis et al. 2006; Pavan and Tavares 2020). Feijó and Rocha (2017) registered pregnant females at the end of December in the municipality of Aiuaba (Ceará), which corresponds to the end of the dry season and the beginning of the rain season. The results presented here confirm this pattern; pregnant females were collected in January at the beginning of the rain season. However, the record of a lactating female in January differs from that reported by Nowak (1994), who recorded births in May at the end of the rain season. 


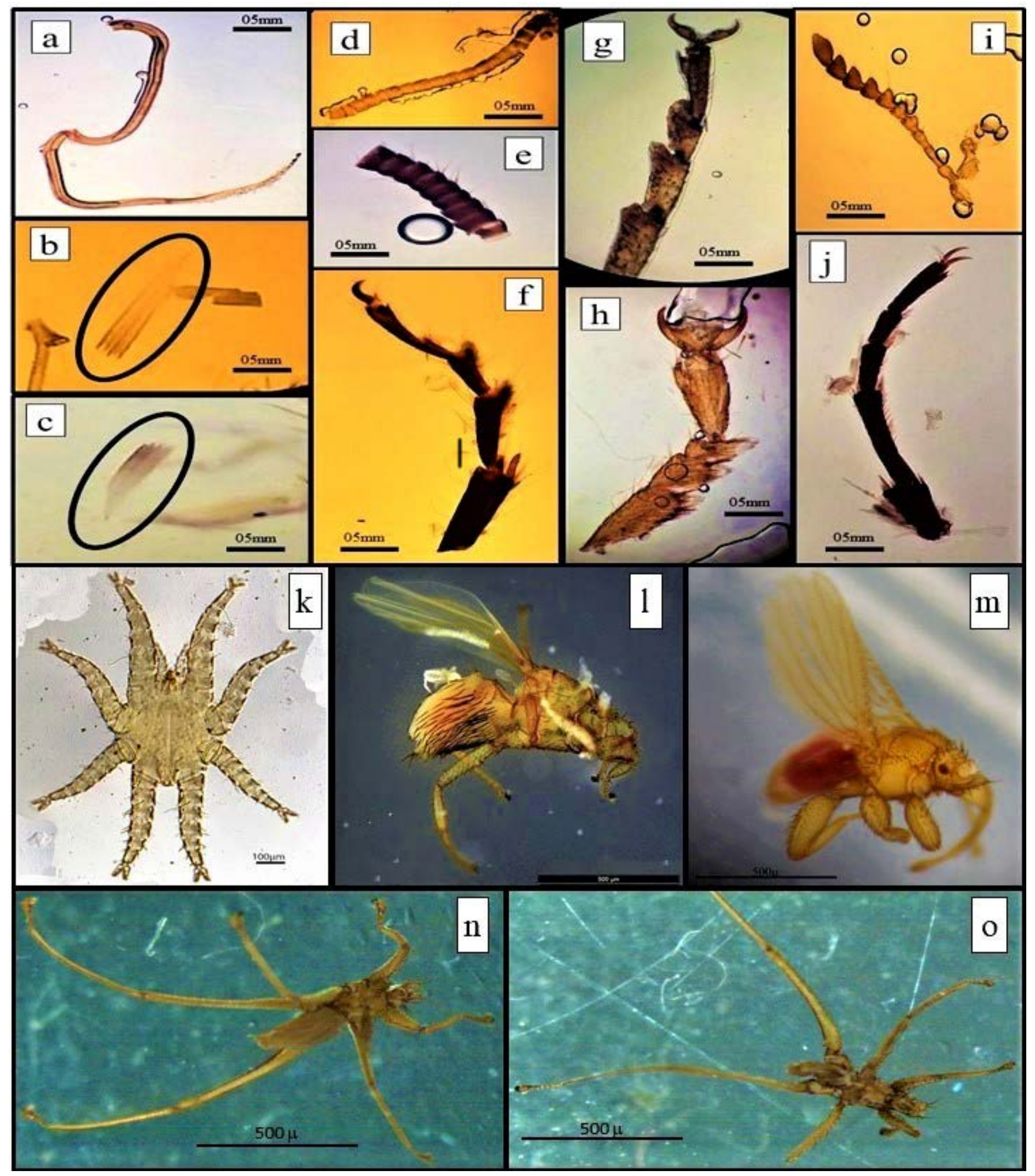

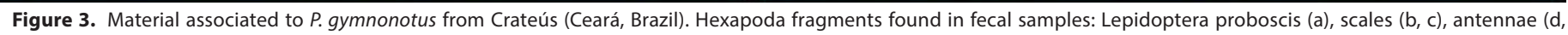

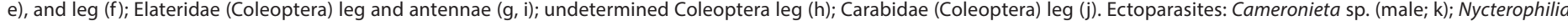

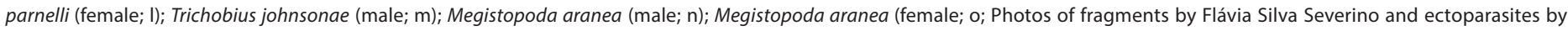
Juliana Cardoso de Almeida).

With a strictly insectivorous diet, Mormopid bats food items include mainly coleopterans and lepidopterans, and smaller quantities of dipterans, orthopterans, homopterans, odonates and hymenopterans (Howell and Burch 1974;
Whitaker and Findley 1980; Mancina 2005; Rolfe and Kurta 2012; Pavan and Tavares 2020). According to Rolfe and Kurta (2012), factors such as sex, age and reproductive condition could influence the feeding preference of insectivorous bats. 
The consumption of Lepidoptera (15.4\%) and Coleoptera (15.4\%) in SANR reinforces the preference for these groups of Hexapoda. Some individuals consumed a combination of prey that included Coleoptera + Lepidoptera, which represented the highest percentage of fragments found (31\%). These results differ from those found by Whitaker and Findley (1980), who recorded a preferential intake of Coleoptera, followed by a much smaller amount of Hymenoptera and, lastly Lepidoptera; the Coleoptera family consumed was not mentioned by the authors. The difference in diet found in this study with that recorded by Whitaker and Findley (1980) may be related to the local entomofauna where the studies were carried out. Studies conducted by Molinari et al. (2000) in Venezuela indicated that P. gymnonotus consumes 35 families of insects from ten orders, of which Coleoptera is the most representative. Howell and Burch (1974) observed the ingestion of only lepidopterans by $P$. gymnonotus in Costa Rica. In the case of SANR food residues, only the consumption of moths from family Sphingidae was verified.

Parasitological studies on South America Mormopids bats were conducted by Guerrero (1985), Guerrero et al. (2003; 2006) and Travassos (1965). These authors identified microfilaria (Nematoda) in the systemic blood and intestine of $P$. parnellii. The necropsied individuals of $P$. gymnonotus from SANR did not display any endoparasites. Helminthic infestations for this species reported in the literature are unknown. There are only records of Trypanosoma wauwau hemoparasites in the states of Pará and Sergipe (Lima et al. 2015; Pavan and Tavares 2020).

Studies on P. gymnonotus ectoparasites collected in the Caatinga biome are scarce. The only records are cited by Almeida et al. (2016) and Luz et al. (2016). The former was conducted in SANR and lists Cameronieta sp. (Spinturnicidae) in association with this species in the area. Regarding Diptera, the results of the present study are significant considering that Frank et al. (2014) reported Nycterophilia parnelli in association with P. davyi and P. parnellii in Belize, Costa Rica and Venezuela; Trichobius johnsonae parasitizing $P$. davyi in Belize, Costa Rica and Venezuela; P. gymnonotus in Venezuela and Panama; P. parnellii in Belize; and P. personatus in Venezuela and Panama. That is, all of these fly species are new records for $P$. gymononotus in Brazil. The association of Megistopoda aranea with P. gymnonotus is a new evidence that makes this mormopid bat a potential new host for this Diptera species. Although a protocol to avoid contamination was implemented, further investigation is required.

\section{Acknowledgments}

We would like to express our gratitude to the following: the Associação Caatinga for the authorization to carry out fieldwork in the Serra das Almas Private Natural Heritage Reserve; S. C. Moreira (UFRJ) for preparing the map; A. P. Cruz, M. Martins, J. S. Damascena, and R. P. Rocha for assisting with the fieldwork; A. P. Cruz for providing the photographs; and the Conselho Nacional de Desenvolvimento Científico e Tecnológico (CNPq; Process No. 470935/2011-1) for the financial support.

\section{Literature cited}

Almeida, J. C., D. Gettinger, and S. L. Gardner. 2016. Taxonomic review of the wingmite genus Cameronieta (Acari: Spinturnicidae) on Neotropical bats, with a new species from northeastern Brazil. Comparative Parasitology 83:212-220.

Alvares, C. A., J. L. Stape, P. C. Sentelhas, J. L. M. Gonçalves, and G. SParovek. 2013. Köppen's climate classification map for Brazil. Meteorologische Zeitschrift 22:711-728.

Associação CaAtinga. 2012. Plano de Manejo da Reserva Natural Serra das Almas. 3a Interação, Crateús.

Baptista, M., AND C. E. L. Esbérard. 1997. Valores hematológicos de Artibeus sp. e Desmodus rotundus (Mammalia, Chiroptera). Revista Científica do Instituto de Pesquisa Gonzaga da Gama Filho 3:11-22.

Bredt, A., W. Uieda, and E. D. Magalhães. 1999. Morcegos cavernícolas da região do Distrito Federal, centro-oeste do Brasil (Mammalia, Chiroptera). Revista Brasileira de Zoologia 16:731-770.

Burgin, C. J., J. P. Colella, P. L. Kahn, and N. S. Upham. 2018. How many species of mammals are there? Journal of Mammalogy 99:1-14.

Czaplewski, N. J., and C. Cartelle. 1998. Pleistocene bats from cave deposits in Bahia, Brazil. Journal of Mammalogy 79:784-803.

Denzinger A., And H U. Schnitzler. 2013. Bat guilds, a concept to classify the highly diverse foraging and echolocation behaviors of microchiropteran bats. Frontier Physiology 4:1-15.

Dick, C. W., G. Graciolli, and R. Guerrero. 2016. Family Streblidae. Zootaxa 4122:784-802.

Feijó, A., And P. A. Rocha. 2017. Morcegos da Estação Ecológica Aiuaba, Ceará, nordeste do Brasil: uma unidade de proteção integral na Caatinga. Mastozoología Neotropical 24:333-346.

Figueiredo, D., G. Graciolli, and L. M. S. Aguiar. 2015. New records of bat flies (Diptera, Streblidae and Nycteribiidae) in Cerrado of central Brazil. Check List 11:1-5.

Flechtmann C.H.W. 1990. Ácaros de importância médica e veterinária. Nobel. São Paulo, Brasil.

Frank, R., J. Münster, J. Schulze, A. Liston, and S. Klimpel. 2014. Macroparasites of Microchiroptera: Bat Ectoparasites of Central and South America. Pp. 87-130, in Bats (Chiroptera) as Vectors of Diseases and Parasites - Facts and Myths (Sven, K., and $\mathrm{H}$. Mehlhorn, eds.). Springer-Verlag. Berlin, Germany.

Guerrero, R. 1985. Parasitología. Pp. 35-91, in El Estudio de los Mamíferos en Venezuela. Evaluación y Perspectivas (Aguilera, M., ed.). Fondo Editorial Acta Científica Venezolana. Caracas, Venezuela.

Guerrero, R. 1993. Catálogo de los Streblidae (Diptera: Pupipara) parásitos de murciélagos (Mammalia: Chiroptera) del Nuevo Mundo. I. Clave para los géneros y Nycterophilinae. Acta Biológica Venezuelica 14:61-75.

Guerrero, R. 1994. Catálogo de los Streblidae (Diptera: Pupipara) parásitos de murciélagos (Mammalia:Chiroptera) del Nuevo Mundo. IV. Trichobiinae com alas desarrolladas. Boletim de Entomología Venezuela 9:161-192.

Guerrero, R. 1995. Catálogo de los Streblidae (Diptera: Pupipara) parásitos de murciélagos (Mammalia: Chiroptera) del Nuevo Mundo. III. Los grupos: dugesii, dunni y phyllos- 
tomae del género Trichobius Gervais, 1844. Acta Biológica Venezuelica 15:1-27.

Guerrero, R., C. Martin, and O. Bain. 2003. Litomosoides yutajensis $\mathrm{n}$. sp., first record of this filarial genus in a mormoopid bat. Parasite 10:219-225.

Guerrero, R., O. Bain, T. Attout, and C. Martin. 2006. The infective larva of Litomosoides yutajensis Guerrero et al., 2003 (Nematoda: Onchocercidae), a Wolbachia-free filaria from bat. Parasite 13:127-130.

Herd, R. M. 1983. Pteronotus parnellii. Mammalian Species 209:1-5.

Howell, D. J, AND D. Burch. 1974. Food habits of some Costa Rican bats. Revista de Biologia Tropical 21:281-294.

Instituto Nacional de Meteorologia (INMET). Temperatura Média Compensada $\left({ }^{\circ} \mathrm{C}\right)$. Available from: https://clima.inmet.gov.br/ GraficosClimatologicos/DF/83377. Accessed on 15 May 2020.

Ladle, R. J., J. V. L. Firmino, A. C. M. Malhado, and A. RodriGUEz-DuRán. 2012. Unexplored diversity and conservation potential of neotropical hot caves. Conservation Biology 26:978-982.

Lima, L., O. Espinosa-Álvarez, C. M. Pinto, M. Cavazzana Jr., A. C. Pavan, J. C. Carranza, B. K. Lim, M. Campaner, C. S. A. Takata, E. P. Camargo, P. B. Hamilton, and M. M. G. Teixeira. 2015. New insights into the evolution of the Trypanosoma cruzi clade provided by a new trypanosome species tightly linked to Neotropical Pteronotus bats and related to an Australian lineage of trypanosomes. Parasites and Vectors 8:1-18.

Luz, H. R., S. Muñoz-Leal, J. C. Almeida, J. L. H. Faccini, and M. B. LabrunA. 2016. Ticks parasitizing bats (Mammalia: Chiroptera) in the Caatinga Biome, Brazil. Brazilian Journal of Veterinary Parasitology 25:484-491.

Machado-Allison, C. E. 1965. Notas sobre Mesostigmata Neotropicales III. Cameronieta thomasi: nuevo género y nueva especie parasita de Chiroptera (Acarina, Spintumicidae). Acta Biológica Venezuelica 4:243-258.

Mancina, C. A. 2005. Pteronotus macleayii. Mammalian Species 778:1-3.

Mares M. A., M. R. Willig, K. E. Streilein, and T. E. Larcher JR. 1981. The mammals of northeastern Brazil: a preliminary assessment. Annals of the Carnegie Museum of Natural History 50:81-137.

Molinari, J., A. Ascenção, and E. K. V. Kalko. 2000. Feeding ecology of the naked-backed bats, Pteronotus gymnonotus and P. davyi, in Venezuela. Pp. 130, in Abstracts of the Annual North American Symposium on Bat Research (NASBR), NASBR 30. Miami, U.S.A.

Nogueira M. R., I. P. Lima, G. S. T. Garbino, R. Moratelli, V. C. TAvares, R. Gregorin, and A. L. Peracchi. 2018. Updated checklist of Brazilian bats: versão 2018. Comitê da Lista de Morcegos do Brasil-CLMB. Sociedade Brasileira para o Estudo de Quirópteros (Sbeq). https://www.sbeq.net/lista-de-especies. Accessed on 15 May 2020.

Norberg U. M., AND J. M. Rayner. 1987. Ecological morphology and flight in bats (Mammalia; Chiroptera): wing adaptations, flight performance, foraging strategy and echolocation. Philosophical Transactions of the Royal Society B 316:335-427.

Novaes, R. L. M. 2012. Morcegos e cavernas: história escondida de evolução, conservação e preconceito. Ciência Hoje 49:40-44.
Novaes, R. L. M., and R. S. Laurindo. 2014. Morcegos da Chapada do Araripe, Nordeste do Brasil. Papéis Avulsos de Zoologia 54:315-328.

Nowak, R. M. 1994. Bats of the World. Johns Hopkins University Press. Baltimore, U.S.A.

Patton, J. L., And A. L. Gardner. 2007. Family Mormoopidae. Pp. 376-384, in Mammals of South America. Volume 1: Marsupials, xenarthrans, shrews, and bats (Gardner, A. L., ed.). University of Chicago Press. Chicago, U.S.A.

Pavan, A. C., and V. C. Tavares. 2020. Pteronotus gymnonotus (Chiroptera: Mormoopidae). Mammalian Species 52:40-48.

Quintela, F. M., C. A. Da Rosa, And A. Feijó. 2020. Updated and annotated checklist of recent mammals from Brazil. Annals of the Brazilian Academy of Sciences 92:e20191004.

Reis, N. R., A. L. Peracchi, W. A. Pedro, And I. P. Lima. 2006. Mamíferos do Brasil. Imprensa da Universidade Estadual de Londrina. Londrina, Brazil.

Rolfe, A. K., AND A. Kurta. 2012. Diet of Mormoopid bats on the Caribean Island of Puerto Rico. Acta Chiropterologica 14:369-377.

Simmons, N. B. 2005. Order Chiroptera. Pp. 312-529, in Mammal Species of the World: A Taxonomic and Geographic Reference. Vol 1. 3rd ed. (Wilson, D. E., and D. M. Reeder, eds). Johns Hopkins University Press. Baltimore, U.S.A.

Simmons, N. B., AND T. M. Conway. 2001. Phylogenetic relationships of Mormoopid bats (Chiroptera: Mormoopidae) based on morphological data. Bulletin of the American Museum of Natural History 258:1- 97.

Sмıтн, J. D. 1972. Chiropteran evolution. Pp. 49-69, in Biology of bats of the New Word Family Phyllostomatidae part I. (Baker, R. J., J. K. Jones Jr., and D. C. Carter, eds.). Special Publications of the Museum no. 10, Texas Tech University Press, Lubbok, U.S.A.

SмIтH, J. D. 1972 a. Systematics of the chiropteran family Mormoopidae. Miscellaneous Publications, University of Kansas, Museum of Natural History 56:1-132.

Silva S. S. P., D. Dias, M. A. Martins, P. G. Guedes, J. C. Almeida, A. P. Cruz, N. M. Serra-Freire, J. S. Damascena, and A. L. PeracCHI. 2015. Bats (Mammalia: Chiroptera) from the Caatinga scrublands of the Crateús region, Northeastern Brazil, with new records for the state of Ceará. Mastozoologia Neotropical 22:335-348

Straube, F. C., and G. V. Bianconı. 2002. Sobre a grandeza e a unidade utilizada para estimar esforço de captura com utilização de redes-de-neblina. Chiroptera Neotropical 8:150-152.

Travassos, L. 1965. Contribuição para o inventário crítico da zoologia no Brasil: Fauna helmintológica: considerações preliminares - cestódeos. Publicações Avulsas do Museu Nacional, Rio de Janeiro 48:1-84.

Wenzel, R. L., V. J. Tipton, And A. Kiewlicz. 1966. The streblid batflies of Panama (Diptera: Calyptera: Streblidae). Pp. 405675, in Ectoparasites of Panama (Wenzel, R. L. and V. J.Tipton, eds.) Field Museum of Natural History. Chicago, U.S.A.

WILLIG, M. R. 1983. Composition microgeographic variation and sexual dimorphism in caatingas and cerrado bats communities from Northeastern Brazil. Bulletin of the Carnegie Museum of Natural History 23:1-131.

Wiluig, M. R., AND M. A. Mares. 1989. Mammals of the Caatinga: an updated list and summary of recent research. Revista Brasileira de Biologia 49:361-367. 
WhitakeR JR., J. O., AND J. S. Findley. 1980. Foods eaten by some bats from Costa Rica and Panama. Journal of Mammalogy 61:540-544.

Associated editor: Jesús Fernández

Submitted: September 28, 2020; Reviewed: November 10, 2020;

Accepted: December 20, 2020; Published on line: January 20, 2021.

\section{Appendix 1}

Examined material (Abbreviations: ALP - catalogue number for the Adriano Lúcio Peracchi Collection, UFRRJ; REG - specimen released): Pteronotus gymnonotus - ALP 10192, ALP 10194, ALP 10386, ALP 10389, ALP 10390, ALP 10422, REG 107, REG 138, REG 140, REG 141, REG 188, REG 201, REG 314, REG 362. 
BIOLOGY AND PARASITES OF P. GYMNONOTUS

138 THERYA Vol.12(1): 131-137 